CENTRE FOR ECONOMIC HISTORY

THE AUSTRALIAN NATIONAL UNIVERSITY

DISCUSSION PAPER SERIES

LABOUR MARKETS IN RECESSION AND RECOVERY: THE UK AND THE USA IN THE 1920S AND 1930S

TIMOTHY J. HATTON

THE AUSTRALIAN NATIONAL UNIVERSITY AND UNIVERSITY OF ESSEX

MARK THOMAS

UNIVERSITY OF VIRGINIA

DISCUSSION PAPER NO. 2012-1

MARCH 2012

THE AUSTRALIAN NATIONAL UNIVERSITY

ACTON ACT 0200 AUSTRALIA

T 61261253590

F 61261255124

E enquiries.eco@anu.edu.au

http://rse.anu.edu.au/CEH 


\title{
Labour Markets in Recession and Recovery: The UK and the USA in the 1920s and
}

1930s.

\author{
By \\ Timothy J. Hatton \\ (Australian National University and University of Essex)
}

\author{
And \\ Mark Thomas \\ (University of Virginia)
}

February 2012

\begin{abstract}
We examine the labour market experience of the UK and the US in the recessions of the early 1920 s and the early 1930s and the subsequent recoveries. These were deep recessions, comparable to that of 2008-9, but the recoveries were very different. In the UK the recovery of the 1920s was incomplete but that of the 1930s was rather less protracted than in the US. By contrast the US experienced very strong recovery in the 1920s but weaker recovery from the much deeper recession of the 1930s. A key ingredient to understanding these patterns is the interaction between economic shocks and labour market institutions. Here we survey the large literature on interwar labour markets to identify the key elements that underpinned labour market performance. We find that developments in wage setting institutions and in unemployment insurance inhibited a return to full employment in interwar Britain while in the US, New Deal legislation impeded labour market adjustment in the 1930s. We conclude with an assessment of the policy responses to labour market crises in the past and in the present.

JEL codes: J64, J65, N12, N14.

Acknowledgements. This chapter is a revised version of an earlier paper that was presented at the British Academy conference Lessons from the 1930s Great Depression for the Making of Economic Policy, and that subsequently appeared in the Oxford Review of Economic Policy, Vol. 26, pp. 463-485. Special thanks are due for helpful comments from our discussant at the conference Chris Minns, to Price Fishback and Wendy Carlin, two anonymous referees, and to the editors Nick Crafts and Peter Fearon.
\end{abstract}




\section{Introduction}

The sharp and deep recession that followed the Global Financial Crisis invites comparison with the Great Depression of the 1930s. Most of the initial focus in the literature has been on comparing the magnitude of the demand side shocks, and the strength and effectiveness of the policy response (Almunia et al., 2010). Attention has now turned firmly to the role of monetary and fiscal policies policy in speeding up or slowing down the recovery. Here too, historical comparisons are instructive (Crafts and Fearon, 2010). However, a sustained recovery depends not just on aggregate demand effects but also on how well the supply side responds. As the interwar period is famous above all for its persistently high unemployment, it is natural to look at the labour market response in that era.

In this paper, we focus not only on the Great Depression of the 1930s but also on the 1920s, especially the early 1920s. The downturn of 1920-22 was short and sharp with an early recovery, while that of the 1929-31 was the prelude to a protracted period of high unemployment. Our approach is to compare the UK and the US in the two recoveries in the hope of gaining greater insight into the economic and institutional factors that were at work. For our underlying framework we draw on a literature that stresses the role of labour market institutions and their interactions with economic shocks as sources of labour market rigidity (Nickell, 1997; 2000; Blanchard and Wolfers, 2000, Layard et al., 2005).

We argue that in the UK, the equilibrium unemployment rate shifted up in the 1920s (as compared with pre World War I), with no further shift in the 1930s. By contrast the US labour market behaved in the 1920s much as in the pre World War I period, but equilibrium unemployment rose in the 1930s. Higher UK unemployment in the 1920s owed much to the evolution of labour market institutions: the rise of trade unionism, the widening scope of collective bargaining, and the advent of a national system of unemployment insurance, as well as a sharp cut in working hours. These developments were either more muted or totally 
absent in the United States. In the 1930s there was little institutional change in the UK labour market, although some of the rigidities stemming from the 1920s remained. But policies under the New Deal led to growing labour market rigidity in the US. These included agreements on working hours and minimum wages and the introduction of relief projects. We then explore two potential causes of unemployment hysteresis: the spatial dispersion of unemployment and the rise of long-term unemployment. We suggest that the interaction of shocks and institutions caused the depression to persist in the late 1930s and we argue that high unemployment was ultimately brought it to by the onset of the Second World War, with little help from equilibrating forces in the labour market. Finally we draw some comparisons between labour market conditions in the interwar period and in the current global recession.

\section{Unemployment, Wages and Prices}

The profiles of the unemployment rate in the UK and the US during the interwar period are generally well known. But it is worth extending the comparison back to the period before the First World War. Comparisons before and after the First World War are possible using the series provided by Boyer and Hatton (2002) for the UK and by Weir (1992) for the US. ${ }^{1}$ These series are plotted in Figure 1. They illustrate that from 1890 to 1913 average unemployment rates were very similar in the two countries: 6.0 percent for the UK and 5.7 percent for the US. Movements in unemployment between the two countries were not highly synchronised - the correlation coefficient is only 0.2 . But there are similarities in the short sharp recession of 1907-8 and the more protracted slump of the 1890s. However, the most important point to emerge is that until the 1920 s the unemployment rate never exceeded 10 percent in either country.

\footnotetext{
${ }^{1}$ Although these are the best available time series, the methods of construction differ over time and between countries. The UK data are based on trade union unemployment rates before 1914 and on unemployment insurance statistics in the interwar period. The US data are based on estimates of employment and interpolated figures for the labour force.
} 
By contrast average unemployment rates were substantially higher in the interwar period. For 1920-39 they averaged 10.5 percent in the UK and 9.7 percent in the US; the correlation between the two series is also stronger at 0.83 . As Figure 1 shows, there was a sharp increase in unemployment between 1920 and 1921 which pushed the unemployment rate above 10 percent in both countries. But then the histories diverge: while the US unemployment rate fell to levels resembling the pre-War average the UK unemployment rate did not. ${ }^{2}$ For our purposes this is important because it is indicative of changes in the UK labour market that were not shared with the US. Unemployment rose steeply in both countries after 1929 but the recession was much worse in the United States where the unemployment rate peaked at 23 percent in 1932 as compared with 17 percent in the UK. After then, unemployment then fell somewhat faster in the US than in Britain, reaching its lowest point in 1937 by which time the unemployment rate was 9.2 percent, compared to 8.5 percent in the $\mathrm{UK}^{3}$

Annual inflation rates for prices and wages are displayed in Figures 2 and 3. For both countries prices were fairly stable before 1914 with slightly more volatility in the US than in the UK. The First World War saw prices soar in both countries with peak inflation rates in excess of 20 percent in 1917. This was followed by a severe deflation between 1920 and 1922, which saw the GDP deflators fall by nearly 25 percent in both countries. Nominal wage rates followed a similar pattern. For the rest of the 1920 s price and wage fluctuations in the UK were fairly mild with some upward drift at the end of the 1930s. In the US there were larger gyrations in the early 1930 s with the price level falling by more that 20 percent between 1929 and 1933, followed by milder fluctuations for the rest of the 1930s.

The causes and effects of fluctuations in wages and prices have been widely studied and we comment only briefly on the results. Multi-country studies of wage setting have

\footnotetext{
${ }^{2}$ This is also reflected in the correlation between the two series, which is 0.49 for $1920-9$ and 0.87 for $1929-38$.

${ }^{3}$ The US figures, following Weir (1992), count relief workers as employed. If they are treated as unemployed, the unemployment rate peaks at 25\% in 1933 and reaches a low in 1937 of $14 \%$.
} 
generally found a degree of nominal inertia in wage setting (Newell and Symons 1988; Bernanke and Carey, 1996; Madsen, 2004). The consensus is that nominal inertia was somewhat greater for wages than for prices. Thus a demand shock raised the real (product) wage, especially in the manufacturing sector, and caused (or at least added to) the decline in employment in the early 1930s. Studies for the UK typically find that employment was negatively related to the real wage; the main difference among them being the degree to which other variables also mattered (Beenstock and Warburton, 1991; Dimsdale et al. 1989; Hatton, 1988). Much of the research agenda on the US labour market of the 1930s has been directed at finding an explanation for the 'puzzling' positive correlation of unemployment and real wages (Jensen, 1989, O'Brien, 1989; Hanes, 2000; Cole and Ohanion, 2004; quote from Margo, 1993, p. 43).

In Table 1 we analyse the unemployment rates observed in Figure 1 by relating them to price and wage changes using an inverted Phillips curve. The natural log of the unemployment rate is related to its own lagged value and to price or wage shocks as represented by the change in the relevant inflation rate. This can be derived from a model with nominal inertia in wage setting and a downward sloping labour demand curve (see Appendix). In the long run this equation provides a version of the Non-Accelerating Inflation Rate of Unemployment (NAIRU). The purpose here is to explore further the differences in unemployment behaviour in the 1920s and 1930s as compared with before the First World War. In each regression we introduce a dummy for 1921 to 1939 and another dummy for 1930-9. These two dummies, starting in the years following the cyclical peaks, are intended to capture shifts in the NAIRU. For both countries the regressions are estimated over 1891 to 1939, omitting the years 1914 to 1919.

The first two regressions in Table 1 show that there is considerable persistence in the UK unemployment rate as reflected in the coefficient on the lagged dependent variable. 
Unemployment is negatively related to price or wage shocks and in both regressions there is a significant upward shift in the unemployment rate from 1921 onwards. Using the wage equation in the second column this implies an increase in the NAIRU for the UK of about four percentage points, from 5.7 percent to 9.5 percent. The coefficient on the dummy for 1930-9 implies a further upward shift, but it is not significant. The same regressions for the US are shown in the third and fourth columns of the Table. There is about the same level of persistence in the unemployment rate as for the UK but somewhat smaller price and wage coefficients. By contrast with the UK, the coefficient for 1921 onwards is negative and not significant while the coefficient for the 1930-9 dummy is positive and significant. Using the wage equation this implies a significant increase in the NAIRU of more than 12 percentage points, from 4.2 percent to 16.9 percent. $^{4}$

The rise in average unemployment in the 1930s probably overestimates the increase in the NAIRU as both countries struggled to recover from the global shock. To the extent that the two countries experienced common shocks that are not accounted for in this simple model this can be overcome by estimating in differences. In the fourth and fifth columns of Table 1 , the dependent variable is the difference between the logs of the UK unemployment rate and the US unemployment rate, with the other variables treated similarly. The constant in these equations is very close to zero, indicating that there was essentially no difference before 1914. While lagged unemployment gives results that are similar to those in columns 1-4, differences in wage and price shocks are insignificant. In part, this reflects the fact that the shocks are correlated; the correlation coefficient over the estimation period is 0.7 for price shocks and 0.4 for wage shocks. The dummy for 1921 onwards is strongly positive implying that the UK NAIRU shifted up relative to the US in the 1920s while the dummy for the 1930s is negative implying that this was (more than) reversed in the 1930s.

\footnotetext{
${ }^{4}$ As an alternative, the regressions for the US were estimated using the series that count relief workers as unemployed (Figure 4 below). The coefficients for the US 1930s dummy are larger (around 0.7 for the US alone and 0.6 for the UK-US difference) but are almost identical in other respects.
} 
The regressions in Table 1 are illustrative rather than definitive. They are based on a simple model of the NAIRU that does not explicitly incorporate demand shocks or structural features of the labour market. Nonetheless, they confirm the differing evolution of average unemployment rates that can be seen in Figure 1. Its key implication is this: if we wish to identify the labour market forces that led to persistently high unemployment we should look at the1920s in the UK and the 1930s in the US.

\section{Labour Markets and Institutions in the 1920s}

Between 1913 and the early 1920s there were radical changes in the UK labour market. Some of these developments had been in train since the 1890s but were sharply accelerated during and immediately after the First World War. To many contemporary observers these changes placed upward pressure on wage rates and made them less flexible, so that negative demand shocks could be less easily accommodated. In 1927 A. C. Pigou wrote:

\footnotetext{
In the post-war period . . . There is strong reason to believe that an important change has taken place in this respect; that, partly through direct state action, and partly through the added strength given to workpeople's organisations engaged in wage bargaining by the development of unemployment insurance, wage rates have, over a wide area, been set at a level which is too high . . . and that the very large percentage of unemployment which has prevailed during the whole of the last six years is due in considerable measure to this new factor in our economic life (Pigou, 1927, p. 355).
}

One key element was the growth of membership in trade unions. Trade union density increased sharply in the years before the War, from 12 percent of the labour force in 1900 to 22 percent in 1913. There were also important changes in the legal background to trade union action, most notably in the Trade Disputes Act of 1906 and the Trade Union Act of 1913. Unionisation increased even more strongly over the War, to peak at 44 percent in 1920 before declining to 26 percent in 1929. As a result, union density in the 1920 s was twice that of the pre-War decade. There were also qualitative changes, as unionism spread to less skilled 
workers in a widening range of industries and (increasingly unskilled) occupations. Not surprisingly, some observers have interpreted interwar wage setting in a formal framework of bargaining between employers and unions (Broadberry, 1986; Matthews, 1986).

The revolution in bargaining over pay was not simply one of numbers. The strength of unions in pay bargaining was also enhanced by the development of formal collective bargaining structures. In 1910 the Board of Trade recorded 1,696 collective agreements covering a total of 2.4 million workers or 13 percent of the labour force. Collective agreements were given a boost during the War by the establishment of Wage Councils which were set up on the recommendation of the Whitley Reports (1917-18). In trades and occupations where there was insufficient organisation among workers and employers for collective negotiation, the gap was filled by Trade Boards that set minimum wages. Established in four low paid sectors under the Trade Boards Act of 1909, their scope was radically expanded in the Trade Boards Act of 1918 and by 1921 there were 63 Trade Boards covering 3 million workers. The Trade Boards diminished in strength during the 1920 s but in 1935 there were still 47 Trade Boards covering 1.1 million workers.

Taken together these forms of centralised wage setting machinery covered about half of the labour force in 1920, declining slightly to 44 percent by 1937 (Thomas, 1992, p. 278). But their structure was very fragmented along industrial and occupational lines. Some observers have argued that wage rigidity is related to the degree of centralisation in the bargaining structure and the degree of co-ordination in wage bargaining across sectors (Calmfors and Driffill, 1988; Soskice, 1990). When unions are strong but the bargaining structure is fragmented and uncoordinated, individual wage bargains do not take into account the economy wide effects of the bargains independently struck in each sector ${ }^{5}$. By contrast,

\footnotetext{
${ }^{5}$ This lack of coordination is illustrated by Keynes' comment a year before the general strike of 1926: “Our export industries are suffering because they are the first to be asked to accept the 10 percent [wage] reduction. If every one was accepting a similar reduction at the same time, the cost of living would fall, so that the lower
} 
with atomistic wage bargaining at the local or firm level, wage bargainers take into account the effect on employment of the high elasticity of demand faced by the individual firm in an industry. Thus potential job losses lead to moderation in wage claims. At the other extreme, when wage setting is coordinated through an encompassing institutional wage structure, a wage increase affects all firms equally. But centralised wage setters are more likely to take into account the economy-wide effects of their actions and therefore to coordinate on a set of wage bargains that would be consistent with high employment. The interwar system of collective bargaining in the UK seems to fall in the region of greater wage rigidity somewhere between the two extremes (Hatton, 1988; Thomas, 1992). ${ }^{6}$

Perhaps the most controversial issue in the debate over unemployment in interwar Britain is the role of unemployment benefits. Until 1911 the only benefits available to the unemployed were from trade union benefit funds or from the Poor Law. Unemployment insurance, first introduced in a few cyclically sensitive sectors, was radically expanded in 1920-1. Coverage increased from 24 percent of the labour force in 1920 to 63 percent in 1921 and from 1921 to 1929 the average benefit to wage ratio for adult male workers was 45.6 percent. In their controversial paper, Benjamin and Kochin (1979) argued that this reduced effective labour supply as workers chose to search longer or less intensively for jobs. However, microeconometric evidence on the incidence of unemployment has not been kind to this argument (Eichengreen 1986, Hatton and Bailey, 2002). It seems more likely that unemployment insurance influenced the wage rates set in collective bargains by further reducing the weight placed on the consequences for unemployment. This is how its influence

\footnotetext{
money wage would represent nearly the same real wage as before. But, in fact, there is no machinery for effecting a simultaneous reduction" (1931, p. 247).

${ }^{6}$ As Soskice (1990) shows, the unemployment outcome will depend on workers' militancy and the bargaining strength of employers as well as on the overall level of aggregate demand. In a fixed exchange rate setting it will also depend on the level of employment that is consistent with balance of payments equilibrium.
} 
was seen by contemporaries and it is a view that has received some support in econometric work on wage setting.

As noted above, persistent unemployment is the outcome of the interaction between shocks and institutions. Most countries experienced a severe demand shock in 1920-1 but the UK also experienced a shock on the supply side. In an influential paper, Broadberry (1990) drew attention to the cut in the average weekly hours of industrial workers that took place in the second half of 1919. This cut of about 13 percent in hours was not matched by a cut in the real weekly wage rate and thus labour productivity declined relative to the real wage. Thus, while economy-wide output per worker was the same in 1923 as in 1913, weekly earnings divided by the GDP deflator had increased by 13 percent. The effect of a negative shock to productivity should have a transitory effect on unemployment which wears off as the real wage adjusts. The evidence suggests that the immediate effect of the productivity shock was to raise the unemployment rate by as much as three percentage points in 1922 but that the effect had largely disappeared by 1929 (Hatton, 2007, p. 486; Thomas, 1994, p. 338).

The United States in the early 1920s presents a very different picture. Union density was about ten percent in the decade before the War, and, although it increased sharply to 17 percent in 1921, by 1923 it was back almost to the pre-War level. The number and scope of collective agreements expanded, but again, much less dramatically than in the UK; in 1925, it was estimated that rather more than 5.5 million workers-or about twenty per cent of the non-farm labour force-were covered by specific wage agreements (Carr, 1925, p. 432). The national system of industrial relations established with the War Labor Board in 1918 was abolished a year later and nothing like it reappeared until the 1930s. Also, the permissive legal environment conferred by the Clayton Act of 1914 was reversed by Supreme Court decisions of 1921 and 1922 (Ebell and Ritschl, 2008). Above all, there was no system of unemployment insurance remotely like the one that emerged in the UK. 
On the other hand working hours had been falling since the $1890 \mathrm{~s}$, a trend that accelerated between 1909 and 1919 when the working week in manufacturing fell by a little over ten percent. The fall in hours occurred more gradually in the US than in Britain (though perhaps less smoothly than Whaples, 1990, suggests ${ }^{7}$ ) and it owed something both to increased militancy and to changes in State hours laws, as well as to organizational shifts within firms in response to technological opportunities. But more importantly it took place against the background of sustained growth in labour productivity and slower growth in labour supply, as immigration dried up during the War. Between 1913 and 1923, economywide output per worker increased by 11 percent in the US, as compared with zero in the UK. And while the resumption of immigration provided a sharp boost to labour supply in 1920 (Vernon 1991, p. 576), it was quickly scotched with the introduction of the Emergency Quota in 1921.

\section{Labour markets in the 1930s}

For the UK, developments in the 1930s run parallel to that of the US in the 1920sessentially no change. Union density drifted mildly downwards in the early 1930s, before recovering to its 1929 level of 26 percent by 1936, and while there was some decline in the coverage of collective agreements the essential structure of pay setting machinery remained unchanged. In 1931 there was a ten percent cut in unemployment benefit, which was restored in 1934. But the fluctuation in unemployment during the 1930s was overwhelmingly due to aggregate demand shocks.

As is well known, demand side activism in the United States was largely a product of the New Deal. But there were significant developments on the supply side too. First and

\footnotetext{
${ }^{7}$ Whaples's analysis is constrained by his sources, namely the Census of Manufactures, only available at five year intervals. Average 'normal' hours in manufacturing industries fell from 57.31 in 1909 to 55.51 in 1914 and 51.36 in 1919-a drop of $7.5 \%$ over 1914/9 (1990, p. 394, n. 3). But evidence from industry-level analysis of hours shows falls of 7.6\% in cotton, $8.6 \%$ in boot and shoes, and 9.2\% in iron and steel between 1918 and 1920 , rather than being distributed evenly over the entire five-year period.
} 
foremost was the National Industrial Recovery Act (NIRA) introduced in 1933, which guaranteed the right of workers to organise trade unions and banned non-union covenants (so-called yellow dog contracts). This led to a dramatic increase in collective bargaining coverage but only a modest increase in union density. Under the National Recovery Administration, codes were developed for 500 industrial sectors covering about 80 percent of private non-agricultural employees. These codes fixed prices, set minimum wages, established maximum hours and set minimum standards for working conditions. When the NIRA was declared unconstitutional in 1935 these measures were continued under the National Labor Relations Act (the Wagner Act), which gave more bargaining power to workers than had the NIRA and encouraged faster growth in unionism. In combination with a more aggressive grass roots movement among labour (Freeman, 1998), which had its most visible impact in the formation of the Congress of Industrial Organizations (CIO) in 1936, a more militant organization that the American Federation of Labor (AFL), unionism grew rapidly. Between 1934 and 1939 union density increased from 11.5 percent to 27.6 percent.

In a pioneering study, Weinstein (1980) compared monthly movements in prices and hourly earnings in 1921-3 and 1933-5. He found that the total impact of the NIRA was to raise prices by 30 percent and average nominal hourly earnings by over 70 percent, increasing unemployment by about 6 percent between 1933 and 1935. Other investigations have suggested that this overstates its effects on wages and prices. Using industry-level data (but not including the early 1920s), Bernanke (1986) argued that the effect of the NIRA was much more modest, raising real hourly earnings by no more than 10 per cent in any individual sector. In a detailed examination of work-sharing policies Taylor (2009) found that the cut in hours from 1933 to 1935 expanded employment by as much as 2.5 million in the covered sector, holding the real wage constant, but that this was largely offset by the effect on labour demand of the increase in hourly earnings. Using a two-sector dynamic general 
equilibrium model, Cole and Ohanian (2004) argue that the effect of New Deal-sponsored 'cartelisation' (including both the NIRA and the NLRA) was to raise the covered sector real wage by nearly 20 percent between 1934 and 1939 and to increase the economy wideunemployment rate by about 6 percentage points.

Of course New Deal policies only came into effect after unemployment had reached its peak. By this time a significant real wage increase of around 16 percent had already taken place as the sharp fall in the price level outpaced the more modest decline in wage rates. Indeed, there was almost no fall in hourly earnings in manufacturing until late in 1931 (Bordo et al. 2000; Hanes 2000; O'Brien 1989) — in contrast with the experience of the early 1920s. Accordingly, some observers have argued that Hoover's high wage policies produced effects that foreshadowed those of the New Deal. ${ }^{8}$ Thus, even if the job losses caused directly by the advent of the New Deal were modest, it nevertheless had the effect of propping up the real wage at a time when the scale of unemployment suggests it should have been falling. Bordo et al. (2000, p. 1460) calculate that a normal recovery would have required a further 10-15 percent fall in real wages, concluding that "even if the NIRA only kept real wages from falling, such a policy would have significantly impeded recovery".

The other important feature of the New Deal was the expansion of work relief programs. These were administered through a sequence of different organisations, which were either run directly by the Federal government or operated through state and local government, and some of which were targeted specifically to young workers. ${ }^{9}$ In a controversial article Darby (1976) argued that those who were on some form of work relief

\footnotetext{
${ }^{8}$ These policies include Hoover's use of moral suasion to induce leading employers not to cut wage rates (Vedder and Galloway, pp. 89-95; Rose, 2010); a series of court rulings beginning in 1929, that supported union rights to organize (Ebell and Ritschl 2008, pp. 23-25); and subsequent supportive legislation embodied in the Davis-Bacon Act of 1931 and the Norris LaGuardia Act of 1932 (Ohanian 2009, pp 2316-18).

${ }^{9}$ Work relief programs were established in 1930-2 but these were modest compared with what followed. The major relief programs were operated under the Civil Works Administration (November 1933 to July 1934); the Federal Emergency Relief Administration (April 1934 to December 1935); and the Works Progress Administration (July 1935 to June 1943). Youth programmes were operated by the Civilian Conservation Corps (April 1933 to June 1943); and the National Youth Administration (January 1936 to May 1943).
} 
should be counted as employed rather than as unemployed (as in the standard BLS-Lebergott series). Those on work relief averaged 30 percent of the unemployed between 1933 and 1940 and re-classifying them as employed makes the depression in the labour market look much milder (Figure 4). Darby claimed that relief work crowded out private sector employment one for one, but a direct test of this hypothesis using aggregate time series data indicated that there was no crowding out (Kesselman and Savin 1978).

Cross sectional analysis has been equally indecisive. Wallis and Benjamin (1981) found that relief spending had no effect on private sector wages and employment in 1934/5 while Fleck (1999) found that relief jobs had no effect on the numbers remaining jobless in 1937 and 1940. These results seem inconsistent with the finding that public works and relief spending had strong positive effects on local consumer demand (Fishback et al, 2005). However dynamic panel analysis at the city level offers some reconciliation. Using vector autoregression, Neuman et al. (2010) find that relief spending increased earnings and employment in the short run but that the long run effect on employment was negative. In the long run, the creation of a relief job crowded out about half to two thirds of a private sector job. And if relief jobs retained some workers in the labour force who would otherwise have withdrawn, then the overall effect on the jobless total may have been minimal (Fleck, 1999, p. 683; Fishback 2007, p. 400).

Jensen (1989, p. 577) characterized those on work relief as 'the least skilled, the least employable.' This judgment is backed by Margo's (1991) analysis of the individual characteristics of relief workers compared to the unemployed, as having 'even less schooling,' and being drawn more consistently out of the ranks of the unskilled $(50 \%$ cited their regular jobs as unskilled labourer, compared to $25 \%$ for the unemployed, and $11 \%$ for those with jobs). Over time, those on work relief became even less employable, as their skills atrophied and their reputations became tarnished by association with federal support. In the 
words of one critic, 'The long years of unemployment which has been his lot since 1931 have naturally resulted in a deterioration of the little skill of which he was possessed' (Monthly Labor Review, 1939, p. 810). In this light it is not surprising that relief workers seem to have exerted very little pressure in the competition for jobs.

\section{The Incidence and Dynamics of Unemployment}

One of the recurring themes in studies of the interwar labour market is that unemployment was very unevenly distributed. The incidence of unemployment varied widely by region, by industry, by occupation and by skill-level. For the UK the most enduring impression of unemployment throughout the interwar period is the dramatic differences between industrial sectors. Not surprisingly some observers have interpreted the unemployment problem in interwar Britain as, in some sense, a structural problem (Booth and Glyn, 1975). In the 1920s the highest unemployment rates (those over ten percent) among insured workers were concentrated largely in the great staple export industries (textiles, iron and steel, engineering and shipbuilding, coal) as well as the building trades. In the 1920s their plight is often associated with the sterling overvaluation, but a modest devaluation would only have gone part of the way to reducing the wide variation in unemployment rates (Wolcott, 1993). These were the industries that suffered most in cyclical downturns even before the First World War and their position deteriorated further in the worldwide recession of the 1930s.

US unemployment in the 1930s was also marked by significant variation by age, skill, industry and, to a lesser extent than in the UK, by region. In March 1933, the highest unemployment rates were to be found in construction (at over 70\%), with manufacturing and transportation as heavily affected sectors (at around 40\%). Agriculture and services, perhaps unsurprisingly, had the lowest rates (around 15\%). The rank order remained the same 
throughout the 1930s, although the levels declined across the board (Margo, 1991, p. 334). Within manufacturing, Wallis (1989, p. 58) has noted that heavy industries and mining fared the worst during the early depression, compared to light industry and textiles; however, from the trough in 1933, heavy industry saw the fastest growth in employment (and was the only manufacturing sector with more jobs in 1937 than in 1929).

In the UK the staple industries were heavily concentrated by region and so the wide variance observed in industry unemployment rates translates into wide regional variations in unemployment. As Table 2 shows, in London and the South East, the Southwest and the Midlands insured unemployment rates in the late 1920s and late 1930s were not wildly higher than the national averages for the pre-1914 period. As the depression deepened in the 1930 s the variance of regional unemployment rates rose further as the absolute difference between unemployment rates in "Inner Britain" and the "Outer Regions" increased (Hatton 1986). That raises the thorny question of why interregional mobility was so low despite official efforts to promote it. The most plausible explanation is that as workers were queuing for jobs at centrally negotiated rates, those that moved south merely swapped a position in the middle of a longer queue for one at the back of a shorter queue (Hatton, 2003).

While there was noticeable geographical variation in the employment impact of the Great Depression in the US, it was more muted than in the UK. Thus, the coefficient of variation $(\mathrm{CV})$ of unemployment rates by region was only 0.19 in the US in 1940 (0.15 when the evening effects of work relief are included), compared to 0.35 in Britain in 1932 and 0.63 in $1936 .^{10}$ Even so, it is clear that some regions fared worse than others: in the early depression, employment held up best in the South Atlantic region and fell fastest in the Mountain states. The recovery rates show something of a rubber-band effect: the larger the decline between 1929 and 1933, the faster employment rebounded between 1933 and 1937.

\footnotetext{
${ }^{10}$ The CV for US unemployment at the state-level for adult males in 1940 was 0.25 if relief workers are treated as employed and 0.24 if they are treated as unemployed; the CV for UK unemployment at the county level for all workers in 1937 was 0.49 (including women in the US data lowers the CV to 0,23 and 0.22 respectively).
} 
But there are two outlier regions - the Mountain states which rebounded more slowly and the South Atlantic region which expanded faster than predicted (a similar result obtains for 193340 relative to 1929-33). Some of this can be explained by the different industrial mixes in the regions, but Wallis $(1989$, p. 59) finds that about 60 per cent of the total regional variation in employment in the 1930s is still left unaccounted for. However, the local effects of bank failures and the differential regional impact of the NIRA codes, as well as the institutional aspects of the second New Deal, seem to have been fairly small (Rosenbloom and Sundstrom, 1999).

It is instructive also to look at unemployment dynamics. For the UK, analysis of the statistics stemming from the working of the labour exchanges and the unemployment insurance system yields a curious picture. On the one hand there was very high turnover in the labour market. During the 1930 s the average monthly flow into jobs was equivalent to nearly two fifths of the average number of wholly unemployed on the register. ${ }^{11}$ On the other hand the number of long term unemployed (those continuously unemployed for at least a year) increased dramatically. This pattern has led some observers to describe the interwar labour market as 'bifurcated' (Thomas, 1988). This is because the probability of leaving unemployment declined very steeply with the duration of unemployment. In 1929 the probability of exit in the first week of unemployment was about fifty percent but after a year of unemployment the weekly probability of exit was a mere two percent (Hatton, 2003, p. 355). With the sharp increase in layoffs in the 1930s the chances of re-employment declined for all the unemployed, and it was this that gave rise to the most sombre legacy of the depression: the host of long term unemployed that persisted into the $1930 \mathrm{~s}$.

In Britain long term unemployment was probably less than 10 percent of male unemployment in the 1920s, but it rose to exceed a quarter by 1936 (Crafts, 1987, p. 420).

\footnotetext{
${ }^{11}$ For the US, monthly hirings by manufacturing firms accounted for about 6 percent of the stock of unemployed in that sector in March 1933; by May 1938, the proportion had risen to 11.4 percent.
} 
The incidence of long term unemployment also fell very unevenly. It was much higher for men that for women; it declined with skill level; it increased with age; and it varied widely across industrial sectors. This differences are seem seen most clearly in the regional variations noted earlier. As Table 3 shows, even in 1932, the share of long term unemployed in insured unemployment was low in the South and it was still fairly low four years later; but in the most hard hit regions it had risen to more than a third by 1936. Consistent with this, the average interrupted spell length of those on the register increased steeply from South to North and it increased substantially between 1932 and 1936. By contrast, the average unemployment duration of the typical new entrant into unemployment increased less steeply both in the cross section and over time.

Long-term unemployment rose even more sharply in the US during the 1930s. According to the Unemployment Census of 1930, only 2.6 percent of the unemployed had been without work for more than a year. In Buffalo, a city that suffered more than most in the 1930s, long-term male unemployment soared: from 9 percent of total unemployment in 1929, to 21 percent in 1930, 43 percent in 1931, 60 percent in 1932, and 68 percent in 1933 (Jensen, 1989, p. 564). By the mid 1930s, city surveys generally indicated very high proportions: 42 per cent in Springfield, Mass., over 60 per cent in Bridgeport, Conn. in early 1934 (Monthly Labor Review, 1935), and 69 percent in Philadelphia in 1935 (Palmer, 1937). As Table 4 shows, by the time of the 1940 Census, fully a third of those out of work had been unemployed for more than a year (the rates were lower for rural than urban places, while work relief had removed many of the hard-core jobless from the ranks of the unemployed). The regional pattern of long-term unemployment is again much more muted in the US than in the UK. The proportion of long-term unemployed was lower in the South and the West than in the North and the East, but the variation is comparatively small: the CV for the nine US 
regions is 0.23 , relative to 0.50 for the UK regions in 1936 . Once again, the work relief programs further reduced regional variation (the CV falling to 0.14$){ }^{12}$

The question has sometimes been raised as to whether the uneven distribution of unemployment hampered wage adjustment and contributed to persistence or hysteresis in unemployment rates during the 1930s. If wage adjustment in each region was determined by a convex Phillips curve then increasing regional dispersion could add to wage pressure for a given national unemployment rate. However the effect of regional unemployment variance on aggregate wage pressure seems weak. Another possibility is that leading wage bargains were set with reference to the industrial or regional labour markets where unemployment was lowest (Thomas and Stoney, 1971), although it is not clear why high unemployment regions per se should carry less weight in wage setting.

A more plausible explanation relates to long term unemployment. If the long-term unemployed suffer a loss of motivation or an attrition of skills then they might be expected to exert less downward pressure on the wage. In an important paper, Crafts (1989) estimated quarterly wage adjustment equations for the UK using total unemployment and long-term unemployment as explanatory variables and found that the long term unemployed exerted no downward pressure on wages. Similar results have been found for European unemployment in the postwar period (Layard et al. 2005; Llaudes, 2005). In the later 1930s the long term unemployed accounted for a quarter of male unemployment in the UK and upwards of a third in the US. Hence wage pressure was substantially higher than the total unemployment percentages would suggest - an effect that may have been exacerbated by regional imbalances, particularly in the UK. ${ }^{13}$

\footnotetext{
${ }^{12}$ The CV of long-term unemployment across states in 1940 is 0.32 if relief workers are treated as employed and 0.22 if they are treated as unemployed. It is not possible to calculate the dispersion of long-term unemployment at finer levels of disaggregation for the UK.

${ }^{13}$ The figures in Tables 3 and 4 indicate that the share of long term unemployment increases roughly linearly with the unemployment rate. This means that the long term unemployment rate increases with the square of the
} 


\section{Institutions and Shocks}

We have argued that labour market outcomes are the result of the interaction between shocks and institutions. While labour market institutions evolve from deeper long run causes, they are also shaped by shocks. Some observers see labour markets developing through a series of institutional stages where "periods of stasis in the basic rules of the game were punctuated by episodes of rapid change" (Rosenbloom and Sundstrom 2011, p. 5). While the underlying forces for change evolve slowly, economic or political shocks can provide the trigger for episodes of more rapid change. In both the US and the UK economies the background fundamentals include the rise in the complexity of production processes with the concomitant increase in the size of firms and the bureaucratisation of management (Jacoby 2004) as well as the growing aspirations of workers based on rising real incomes, backed by increasing social organisation and political voice.

The reaction of governments to changes in the labour market (and in society more generally) reflected two key elements. One was to cope with the rise of powerful economic interest groups by reconciling them through state intervention and regulation, with the aim of improving economic coordination and fostering more equal treatment (Wallis 2010). Thus to some degree, government activism was designed to stave off social and industrial unrest and preserve the smooth working of the capitalist system. The second was the gradual development of government sponsored insurance and protection against various contingencies. As Moss (2002, Ch 6) points out, the late nineteenth century saw the beginnings of a shift in the focus of government risk management polices from business security towards worker security. By the interwar period the UK and the US were at different

overall unemployment rate in a region. Thus the more unevenly distributed is unemployment the higher the share of long term unemployment in the total. Calculations not reported here (but available from the authors on request) suggest that regional dispersion added about half a percentage point to the long term unemployment rate for the UK in the late 1930 s and somewhat less for the US. 
stages in this evolution, and combined with differences in the nature and intensity of the shocks, this led to somewhat different policy reactions.

Between 1910 and 1920 the institutional structure of the UK labour market underwent dramatic change, but it was largely an acceleration of trends that were already underway. Unionism, especially among the unskilled, had been on the increase since the 1880 s while collective bargaining arrangements grew in scope and centralisation. Minimum wage legislation was first introduced in a very narrow range of occupations in 1909 while unemployment insurance was introduced on a modest scale in $1911 .{ }^{14}$ During the War tight labour markets combined with growing militancy and industrial unrest placed severe pressure on the government to produce formal wage setting arrangements in a wide range of industrial sectors. But in the face of slow productivity growth these more formal arrangements failed to deliver industrial peace until after the general strike of 1926. The rapid extension of unemployment insurance can be seen as a reaction to the implicit threat of insurrection against the background of the Russian revolution. Designed to replace the temporary out of work donation scheme set up in 1918 to ease the transition to a peacetime economy, the unemployment insurance scheme was initially increased in scope and then augmented by a series of emergency measures throughout the 1920s that extended the coverage and the duration of benefit (Garside 1990, pp. 36-43).

In the United States the First World War imposed similar pressures and, as noted earlier, it fuelled unionism and industrial militancy which called forth increasing public intervention. But these trends came to an abrupt halt as pressure eased and militancy finally collapsed in 1922 (Montgomery, 1987, Ch. 9). The reversal owed much to the fact that the effects of the War were shorter and less intense than in the UK, and there was no productivity setback. The wartime period also gave a fillip to growing pressure for social insurance of

\footnotetext{
${ }^{14}$ The pre-War Liberal welfare reforms have also been interpreted as a means of preserving and enhancing the efficiency of the market system by achieving political consensus "at a time of rising antagonism in the political and industrial world," (Harris, 1972, p. 365)
} 
which workmen's compensation was the only tangible result. One of the chief impediments was the difficulty of promoting state-level legislation in the face of fierce competition between the States (Moss, 2002, p. 173-5). But the equilibrium that was underpinned by the benign conditions of the 1920s was overturned by the shock of the Great Depression. The policy of high wages and industrial collusion that began under Hoover, largely to avert the spread of unionism and industrial strife (Ohanian 2009), was transformed into a new institutional structure under the New Deal. These reforms followed rather than led the economic downturn and some, such as the Social Security Act of 1935 and the Fair Labor Standards Act of 1938, only came into effect at the very end of the 1930s.

By contrast, the shock of 1929-1931 did not effect a fundamental reconsideration of the institutional arrangements governing the labour market in Britain, despite the identification by Pigou, Clay and others that these were at the root of the high unemployment of the 1920s. Indeed, the very political pressures that underpinned the development of the ruling post-war institutional framework were intensified in the slump and ensured that any reforms would be limited at best.

Given the underlying imperatives for institutional change it may seem ironic that public intervention added to the unemployment burden. One reason is the lack of available alternatives. In the recent global recession governments around the world have pursued active fiscal and monetary policies to stave off the worst effects of what appeared like another Great Depression. But during the interwar period adherence to the gold standard and to the economic policy regime that went with it precluded such immediate activism, even though it might have been effective (Alumnia et al. 2010). Despite growing recognition that unemployment was an industrial problem rather than an individual problem, the only tools available were direct market interventions. Because such interventions were novel, their likely effects were not as clearly understood as they are with the benefit of historical 
hindsight. Thus, although the effects of unemployment insurance, relief jobs, high wage policies and support for collective bargaining were fiercely contested, carefully considered evidence-based policy was not possible.

The effects of different labour market institutions on the equilibrium rate of unemployment vary widely and they also depend on the structure of the labour market. Analyses of European labour markets in the 1980s and 1990s have found that the outcome for unemployment depends on interactions between institutions and not simply on adding up their individual effects. (Elmeskov et al., 1998; Belot and Van Ours, 2007). Thus in the case of interwar Britain, the unemployment insurance system may have been more harmful in the presence of strong industry level wage setting than otherwise (and vice versa). For the United States, the rise in real wages that took place in the early 1930s might have been less harmful in the long run if it had not been combined under the NIRA with the cartelisation of large segments of industry.

However misplaced these measures may have been, the estimates of their contributions to the overall unemployment rate, either singly or in combination, are still highly uncertain. But once in place they almost certainly contributed to the persistence of unemployment. Before the First World War and even into the interwar period, labour markets were relatively fluid with low job attachment, high labour turnover and relatively short unemployment durations (Thomas, 1988; Jacoby and Sharma, 1992). But institutional change weakened these equilibrating forces and in the slump of the 1930s workers who were initially willing and able to work at the going wage queued for jobs while their skills and motivation atrophied. This in turn weakened wage pressure that might otherwise have hastened the recovery.

\section{Ending the Depression}


We have argued that a combination of shocks and institutions led, by the late 1930s, to equilibrium levels of unemployment that were significantly higher than before. That raises the question of what did bring the depression to an end. To many observers the answer is simple: the Second World War. However, not all agree. One view is that in the absence of the recession of 1937-8, the recovery would have continued and unemployment would (eventually) have fallen to something resembling the 'normal' levels of the more distant past. In that case, the positive shock delivered by the onset of war simply speeded up the ongoing transition to low unemployment. The other view is that, the US and UK economies had reached, or were approaching, labour market equilibrium in the later 1930s, even though unemployment remained comparatively high. In that case the shift to low unemployment could be achieved only by a massive demand shock like war.

In the United States output increased by a staggering 40 percent between the depths of 1933 and the peak of 1937, and unemployment fell steeply (Figure 4). The prevailing view is that this was driven largely by the demand side, particularly the monetary expansion that followed from the regime change of 1933 (Romer, 1992; Eggerston 2008). Nevertheless, equilibration on the supply side probably played some part: although wages and prices increased (largely because of NIRA and the Wagner Act), productivity grew especially strongly over the 1930s (Field, 2003). The downturn of 1937-8 was due to a radical shift in monetary policy - the sterilisation of gold inflows and the doubling of banks' reserve requirements in 1936-7—as well as to a substantial fiscal tightening (Velde, 2009). The sharp recovery in 1938 can largely be accounted for by the reversal of these policies. Hence over the range of unemployment rates down to about 10 percent, the aggregate labour supply curve was highly elastic, and demand shocks had large employment effects. The question is whether, given more time, the labour market might have equilibrated at a substantially lower level of employment. 
The US unemployment rate fell to just under ten percent in 1940 and then dropped to 6 percent in 1941 before dipping below 2 percent in 1943. Was there a 'natural' recovery up to 1941 , before the full force of the War came into effect? Recent research suggests that monetary expansion up to 1940 and the subsequent fiscal expansion were the driving forces rather than labour market equilibration (Vernon, 1994; Gordon and Krenn, 2010). Gordon and Krenn (2010) demonstrate that war-related expenditures gathered pace in 1940 rather than after the Japanese bombing of Pearl Harbour, as is sometimes supposed. Looking at contemporary reports they find that labour shortages were not encountered until late 1941, by which time the unemployment rate was around five percent. However this was not an equilibrium unemployment rate. As Higgs (2006) shows, wage and price controls were introduced early in 1941, something that probably muted the inflation effects of an increasingly tight labour market.

A similar story can be told about the UK. The unemployment rate was 8.5 percent in 1937 and, after a brief downturn it, rebounded to the same level in 1939. After that the stock of unemployment fell steeply from 1.5 million in 1939 to 123 thousand by mid-1942. Up to 1937 the fall in unemployment was driven by monetary and fiscal policies and by expanding world trade. The contribution of rearmament was larger and started earlier than it did in the US. Thomas (1983) shows that the direct and indirect effects of rearmament created a million jobs, accounting for more than four fifths of the increase in civilian employment between 1935 and 1938. By the late 1930s there were reports of labour shortages that some have interpreted as capacity constraints but the evidence is thin. However by 1939 the labour market was tightening and, in advance of the imposition of controls, wage rates jumped sharply in 1940.

The experience in both countries suggests that by the early stages of the War (early 1940 in the UK and mid-1941 in the US) unemployment rates were below what for the 1930s 
were equilibrium levels. In both countries skilled workers, especially those in construction and engineering had been fully mopped up, but there remained a residual of those who in a peacetime setting were virtually unemployable. How, then, did unemployment all but disappear in the months that followed? Clearly vast numbers were recruited into the armed forces (almost 11 million-20 per cent of the civilian labour force-in the US between 1940 and 1944). In the US labour supply increased as youths and married women were added to the labour force (Long, 1944, Ch 8). The expansion of civilian employment also included one and a half million men equally divided between those who would otherwise have retired and those "of doubtful employability who had given up the search for a job after failing to measure up to the relatively rigid requirements of the pre-war labor market" (Eskin, 1944, p. 264). In order to facilitate re-employment New Deal public employment programs were adapted to provide vocational education and training for war-related industries. By February 19423.3 million trainees had been through such programs while almost as many received onthe-job training (Vatter, 1985, p. 43).

In the UK more that 1.5 million men (equivalent to 7 percent of the labour force) had been conscripted into the armed forces by the end of 1939. Some of these came from the ranks of the unemployed but only a few of the long term unemployed found their way into the armed forces. More than half of the long term-unemployed in May 1939 were aged 45 or over and therefore not eligible, and many others were not fit for active service. By early 1940 the unemployed consisted largely of labourers and older workers (George, 1940). Most of these were drawn into civilian or war-related employment and by November 1940 only a very small residual of truly unemployables remained. ${ }^{15}$ Besides the opening of opportunities for

\footnotetext{
${ }^{15}$ The number of long term unemployed fell by half between April 1930 and May 1940. From July 1940 review panels were set up to evaluate those who remained unemployed with the aim of matching them to suitable employment or retraining. Of 152,000 men who were interviewed up to October 1940, more than three quarters were found to be suitable for immediate employment. By that time 'hard core' unemployment was less that 100,000 , and as one observer commented: "large numbers of the so-called unemployables were being drawn
} 
those who were previously considered unemployable there was a series of active labour market policies that directed workers in ways that would have been almost inconceivable in peacetime (Reubens, 1945).

This analysis suggests that in both the UK and the US, the 'self correcting' labour market mechanism was so weak by the 1930s that, in the absence of positive shocks it would not have driven the unemployment rate much below ten percent. The onset of war pushed unemployment below that level but it was not until mass mobilisation took hold that the hard core of unemployment was eliminated. It took a massive shock, combined with an equally radical shift in the institutional structure to finally jolt the labour market permanently out of its previous equilibrium.

\section{Then and Now}

There is widespread agreement that the onset of the global financial crisis that began at the end of 2007 looked very much like the initial stages of the Great Depression in terms of its worldwide scope and the trajectories of key indicators such as stock prices, industrial production and world trade. Although not as severe as some expected, the fall in output has been the largest in the postwar period. For the UK the decline of 6 percent between the beginning of 2008 and the end of 2009 was comparable to that between 1929 and 1931. For the US the 6 percent drop in output was much smaller than the massive14 percent experienced between 1929 and 1931. The parallels between the 1930s and now raise the question of whether insights from the past are relevant for today-- and in particular for fostering economic recovery. In this paper we have argued that we need to look at the recession and recovery of the early1920s as well as that of the early 1930s if we want to draw 
the right lessons from the interwar years. We also advocate an approach that has at its core the interaction between shocks and institutions.

One obvious insight from the interwar experience is that deep recessions are likely to trigger severe pressures on governments to intervene in order to avert unrest. In the interwar period those interventions focused largely on the supply side, on holding real wages up and on mitigating the plight of the unemployed, rather than on stimulating aggregate demand. Following the global financial crisis, early and effective intervention on the demand side mitigated the scale of the demand shock. In the early stages of the recession, this averted pressures for extensive direct intervention in the labour market and it provided some justification (even among skeptics) for Keynesian style policies. But while a deeper recession was avoided, the deficit reduction policies announced in 2010 and 2011 seem likely to delay economic recovery.

Fiscal and monetary policies on the scale witnessed in 2008/9 could not have been implemented in the interwar period, given the ideological and administrative constraints, but expectations effects did play a role in the recovery process. Leaving the gold standard, and abandoning the policy dogma that went with it, helped to end the downward spiral (Eichengreen and Sachs 1985; Temin and Wigmore 1990; Eggertsson 2008). But these policy shifts did not come into effect until two years into the recession in the UK and nearly four years into the recession in the US. Nevertheless monetary and fiscal policies had substantial effects during the interwar period, as illustrated by the experience of 1937-8, and even more demonstrably by the effects of rearmament. In the light of this evidence it has been argued that earlier and larger-scale intervention on the demand side could have returned both economies to something resembling normal employment levels well before the War. Here we differ from other interpretations of the potential for recovery that focus entirely on the inadequacies of fiscal and monetary policies. Neither an earlier unshackling of the Golden 
Fetters nor a larger overall stimulus would have been enough unless institutional change in the labour market could have been averted in the case of the US or undone in the case of the UK.

Labour market institutions are probably more favourable to labour market recovery today than they were in the 1930s. In the UK the key institutional developments are the deregulation of wage bargaining that took place in the 1980s and, more recently, the various 'new deals' and welfare-to-work programmes aimed at enhancing labour market flexibility and reducing long term benefit dependence. In the US the renewal of Emergency Unemployment Compensation introduced in 2008, and other programmes introduced under the American Recovery and Reinvestment Act of 2009, may have marginally reduced search efficiency. ${ }^{16}$ But there has been nothing resembling the institutional reforms that were introduced in the 1930s. Nevertheless modern labour markets are less fluid than they were in the past and so a very rapid recovery like that of the early 1920s could not be expected.

In the current recession UK the unemployment rose from 5.4 percent in early 2008 to 7.9 percent three years later, while long term unemployment increased from less than a quarter to more than a third of the total. In comparison to the interwar period the labour market impact has been milder but there is likely to be greater persistence. However, in comparison to the more recent past (and in the absence of positive demand shocks) the signs for the UK are more encouraging. Although the rate of job loss was greater than in any other postwar recession, the rates of outflow from unemployment have held up remarkably well (Elsby et al., 2011). And there has been no outward shift in the relationship between unemployment and vacancies that would signal a decline in labour market efficiency. One

\footnotetext{
${ }^{16}$ Emergency Unemployment Compensation introduced in June 2008 extended the duration of unemployment benefit from 26 to 53 weeks and has been renewed until March 2012. The American Recovery and Reinvestment Act of February 2009 included a variety of infrastructure projects and educational projects as well as subsidies for health care, homeownership, working tax credits and displaced worker support.
} 
reason may be that real wages have declined much more sharply, and this has helped to preserve employment more than in previous recessions (Martin, 2011).

In the US the unemployment rate rose from 4.8 percent at the beginning of 2008 to 9.7 percent three years later. Hence the labour market recession in the US has been far deeper although the shock to output has been similar. Elsby et al. (2010, p. 4) note that the unusually large decline in unemployment outflow rates has been accompanied by a record rise in long term unemployment, which "is likely to result in a persistent residue of long term unemployed workers with relatively weak search effectiveness, depressing the strength of the recovery." Accordingly, there is evidence that the unemployment-vacancies relationship has shifted outwards, implying some reduction in labour market efficiency.

Finally, when seeking insights from the past it is important to stress the differences as well as the similarities. Much of the discussion has now turned to how far deficit-reduction policies are slowing down the recovery and may yet produce a double dip recession. The obvious parallels are with the 1937-8 recession and the role of rearmament in boosting the economy in the run up to the War, in the absence of strong equilibrating forces in the labour market. By contrast, in the present, the combination of shocks and institutions is more benign. While an ongoing demand stimulus would help, the US and UK economies might be expected recover more strongly than in the 1930 s, even in its the absence. In this respect, 1930s pessimism should not be carried over to the present and there is no reason to think that demand shocks on the scale of the early 1940s would be necessary for a full recovery.

A further issue is that of a slowdown in productivity growth. Productivity has sagged in recent recessions and then output has grown faster than labour input in the recovery (Gordon 2010). In the current recession productivity (per worker hour) has fallen much further in the UK than in the US, which has led some to the view that, especially in the UK, the output gap has not widened by as much as trend projections would otherwise suggest 
(Martin 2011). Although in the 1930s, as now, there was a slowdown in capital accumulation, underlying productivity growth remained strong. In this respect, a parallel with the 1930s would be more apposite than one based on the UK productivity slump of 1919/20 or the productivity slowdown of the 1970s. In both these cases, and unlike the present, there were identifiable supply side shocks. As noted earlier, one reason for the UK productivity dip could be the decline in real wages - something that may mean a jobless recovery in the shortrun but an eventual return to low unemployment in the medium term.

\section{Conclusion}

The speed and extent of the economic recovery from a macroeconomic shock is conditioned both by the scale of the shock and by the structure of labour market institutions. The interwar experience can shed light on these issues because it witnessed large economic shocks and significant changes in labour market institutions. The Great Depression is aptly named. It was the worst depression since records began. But it is important to look at the 1920 s as well as the 1930 s.

In the early 1920s the UK and the US experienced macroeconomic shocks, which seem to have been broadly similar in magnitude, and from which the US recovered rather better than the UK. We have argued that there was a distinct increase in the equilibrium unemployment rate in the UK in the 1920s associated with increased union militancy, the development of centralised but uncoordinated wage setting, and the advent of a national system of unemployment insurance. The UK recovery in the 1920s was also hampered by the sharp cut in working hours. By contrast, such institutional developments were largely absent in the US and the fall in working hours was more easily accommodated. The economic shock in the 1930s was more persistent and it was larger in the US than in the UK. In the UK the institutional structure established in the 1920 s probably slowed the recovery and its most important manifestation was the rise in long term unemployment. In the US the demand 
shock and the unemployment response was much larger. But New Deal legislation impeded labour market adjustment in the later 1930s.

What lessons should today's policy makers draw from the interwar experience? Clearly, one is to avoid labour market interventions that directly or indirectly reduce the resilience of the labour market, and thereby stifle the supply side contribution to recovery. Another is that the longer and the more severe are the new debt-driven austerity policies the greater the risk of marginalising sections of the workforce and creating a legacy of persistent unemployment, which only dramatic positive demand shocks can overcome. 


\section{Appendix: Nominal and Real Wage Rigidity and Unemployment}

As noted in the text the regressions that are presented in Table 1 reflect some combination of real wage rigidity and nominal inertia in wage setting. The derivation here follows the original formulation of Grubb, et al. (1983), which has been followed by many others.

Here lower case letters represent the log of a variable: $w$ is the nominal wage, $p$ is the price level $u$ is the unemployment rate and $q$ is productivity. The Phillips curve with nominal inertia can be written as:

$\Delta w_{t}=a \Delta p_{t}+(1-a) \Delta w_{t-1}-a b\left(u_{t}-u_{0}\right)$

Where nominal inertia is captured by $\mathrm{a}<1$ and $u_{0}$ is the NAIRU. Price setting, or alternatively, labour demand is represented by:

$\Delta p_{t}=\Delta w_{t}-\Delta q_{t}-c \Delta u_{t}$

Substituting price setting into the Phillips curve to eliminate price change and putting unemployment on the left gives:

$u_{t}=\frac{b}{b+c} u_{0}-\frac{1}{b+c} \Delta q_{t}+\frac{c}{b+c} u_{t-1}-\frac{1-a}{a(c+b)} \Delta \Delta w_{t}$

For zero productivity growth (or where productivity growth appears directly in the Phillips curve), a constant rate of wage change and a constant unemployment rate, unemployment will be at the NAIRU: $u_{t}=u_{t-1}=u_{0}$. Here real wage rigidity defined by $1 / b$ and nominal wage rigidity defined by $(1-a) / a b$ are not directly identified. But clearly the larger is the coefficient on lagged unemployment the greater is real wage rigidity and the larger is the coefficient on $\Delta \Delta w$, the greater is nominal wage rigidity.

Eliminating the wage gives a slightly more complex expression in terms of price change:

$$
\begin{aligned}
u_{t}=\frac{a b}{a b+c} u_{0} & -\frac{1}{a b+c} \Delta q_{t}+\frac{c}{a b+c} u_{t-1}-\frac{1-a}{a b+c} \Delta \Delta p_{t}+\frac{1-a}{a b+c} \Delta q_{t-1} \\
& +\frac{(1-a) c}{a b+c} \Delta u_{t-1}
\end{aligned}
$$

As before, for constant growth rates of productivity and prices, and a constant unemployment rate, unemployment is at the NAIRU, $u_{0}$. 


\section{References}

Almunia, M., Bénétrix, A., Eichengreen, B., O’Rourke, K. H. and Rua, G. (2010), "From Great Depression to Great Credit Crisis: Similarities, Differences and Lessons," Economic Policy, 25, pp. 219-265.

Beenstock, M, and Warburton, P. (1991), "The Market for Labor in Interwar Britain," Explorations in Economic History, 28, pp. 287-308.

Balke, N. S. and Gordon, R. J. (1986), "Historical Data," in R. J. Gordon (ed.) The American Business Cycle: Continuity and Change, NBER: University of Chicago Press.

Belot, M. V. and Van Ours, J. C. (2004), "Does the Recent Success of some OECD Countries in Lowering their Unemployment Rates Lie in the Clever Design of their Labour Market Reforms?" Oxford Economic Papers, 56, pp. 621-642.

Benjamin, D. K. and Kochin, L. A. (1979), "Searching for an Explanation of Unemployment in Interwar Britain," Journal of Political Economy, 87, 441-78.

Bernanke, B. S. and Carey, K. (1996), "Nominal Wage Stickiness and Aggregate Supply in the Great Depression," Quarterly Journal of Economics, 111, pp. 853-83.

Blanchard, O. and Wolfers, J. (2000), "The Role of Shocks and Institutions in the Rise of European Unemployment: The Aggregate Evidence," Economic Journal, 110, pp. C1-C33.

Booth, A. E. and Glynn, S. (1975), "Unemployment in the Interwar Period: A Multiple Problem,” Journal of Contemporary History, 10, pp. 611-37

Bordo, M., Erceg, C. J. and Evans, C. L. (2000), "Money, Sticky Wages, and the Great Depression," American Economic Review, 90, pp. 1447-1463.

Broadberry, S. N. (1986), “Aggregate Supply in Interwar Britain,” Economic Journal, 96, pp. 467-81.

Broadberry, S. N. (1990), “The Emergence of Mass Unemployment: Explaining Macroeconomic Trends in Britain during the Trans-World War I Period," Economic History Review 43: 272-82.

Boyer, G. R. and Hatton, T. J. (2002), "New Estimates of British Unemployment, 18701913," Journal of Economic History, 62 (2002), 643-75.

Calmfors, L. and Driffill J. (1988), "Bargaining Structure, Corporatism and Macroeconomic Performance,” Economic Policy, 6, pp. 13-61.

Carr, E. B. (1925), "The Use of Cost-of-Living Figures in Wage Adjustments," Department of Labor Bulletin, 369, Washington D.C.: Government Printing Office. 
Cole, H. L. and Ohanian, L. E. (2004), "New Deal Policies and the Persistence of the Great Depression: A General Equilibrium Analysis," Journal of Political Economy, 112, pp. 779816.

Crafts, N. F. R. (1989), "Long-Term Unemployment in Britain in the 1930s," Economic History Review, 40, pp. 418-32.

Crafts, N. F. R. (1989), "Long-Term Unemployment and the Wage Equation in Britain, 19251939," Economica, 56, pp. 247-54.

Crafts, N. F. R and Fearon, P. (2010), "Lessons from the 1930s Great Depression," Oxford Review of Economic Policy, 26, pp. 285-317.

Darby, M. R. (1976), “Three-and-a-half Million U.S. Employees have been Mislaid, or an Explanation of Unemployment, 1934-1941," Journal of Political Economy, 84, pp. 1-16.

Dimsdale, N. H., Nickell, S. J. and Horsewood, N. (1989), "Real Wages and Unemployment in Britain during the 1930s," Economic Journal, 99, pp. 271-92.

David, P. A. and Solar, P. (1977). "A Bicentenary Contribution to the History of the Cost of Living in America," Research in Economic History, 2, pp. 1-80.

Ebell, M. and Ritschl A. (2008), "Real Origins of the Great Depression: Monopoly Power, Unions and the American Business Cycle in the 1920s," London School of Economics CEP Discussion Paper 876.

Eggertsson, G. B. (2008), "Great Expectations and the End of the Great Depression," American Economic Review, 98, pp. 1476-1516.

Eichengreen, B. and Sachs, J (1985), "Exchange Rates and Economic Recovery in the 1930s," Journal of Economic History, 45, pp. 925-946.

Eichengreen, B. (1986), “Unemployment in Interwar Britain: Dole or Doldrums?” Oxford Economic Papers, 39, pp. 597-623.

Elmeskov, J., Martin, J. P. and Scarpetta, S. (1998), "Key Lessons for Labour Market Reforms, Evidence from OECD Countries' Experiences," Swedish Economic Policy Review, 5, pp. 205-252.

Elsby, M. L., Hobijn, B. and Şahin, A. (2010), “The Labor Market in the Great Recession," Brookings Papers in Economic Activity, Spring, pp.1-48.

Elsby, M. L., Smith, J. C. and Wadsworth, J. (2011), "The Role of Worker Flows in the Dynamics and Distribution of UK Unemployment," Oxford Review of Economic Policy, 27, pp. 338-363.

Eskin, L. (1944), "Sources of Wartime Labor in the United States," Monthly Labor Review, 44, pp. 264-278. 
Feinstein, C. H. (1972), National Income, Expenditure and Output of the United Kingdom, 1855-1965, Cambridge: Cambridge University Press.

Feinstein, C. H. (1995), "Changes in Nominal Wages, the Cost of Living, and Real Wages in the United Kingdom over Two Centuries, 1780-1990," in P. Scholliers and V. Zamagni (eds.), Labour's Reward, Aldershot: Edward Elgar.

Field, A. (2003), "The Most technologically Progressive Decade of the Century," American Economic Review, 93, pp. 1399-1413.

Fishback, P. V., Horrace, W. and Kantor, S. (2005), "Did New Deal Grant Programs Stimulate Local Economies? A Study of Federal Grants and Retail Sales during the Great Depression," Journal of Economic History, 65, pp. 36-71.

Fishback, P. V. (2007), "The New Deal," in P. V. Fishback (ed.), Government and the American Economy: A New History, Chicago: University of Chicago Press.

Fleck, R. K. (1999), “The Marginal Effect of New Deal Relief Work on County-Level Unemployment Statistics,” Journal of Economic History, 59, pp. 659-87.

Freeman, R. B. (1998), "Spurts in Union Growth: Defining Moments and Social Processes," in M. D. Bordo, C. Goldin and E. N. White (eds.), The Defining Moment: The Great Depression and the American Economy in the Twentieth Century, Chicago: University of Chicago Press.

Garside, W. R. (1990), British Unemployment 1919-1939: A Case Study in Public Policy, Cambridge: Cambridge University Press.

George, C. O. (1940), Comment on R. D. G. Allen (The Unemployment Situation at the Outbreak of War), Journal of the Royal Statistical Society, 103, pp. 211-213.

Gordon, R. J. (2010),"Okun's Law, Prodictivity Innovations and Conundrums in Business Cycle Dating," American Economic Review, 100, pp. 11-15.

Gordon, R. J. and Krenn, R. (2010), "The End of the Great Depression 1939 - 41: VAR Insight on Policy Contributions and Fiscal Multipliers," Northwestern University: Unpublished paper.

Gregg, P. and Wadsworth, J. (2010), "The UK Labour Market and the 2008-9 Recession," National Institute Economic Review, 212, pp. R61-R72.

Hanes, C. (2000), "Nominal Wage Rigidity and Industry Characteristics in the Downturns of 1893, 1929, and 1981," American Economic Review, 90, pp. 1432-46.

Harris, J. (1972) Unemployment and Politics: A Study in English Social Policy, 1886-1914, Oxford: Clarendon Press.

Hatton, T. J. (1986), "Structural Aspects of Unemployment in Britain between the World Wars," Research in Economic History, 10, pp. 55-92. 
Hatton, T. J. (1988a), "Institutional Change and Wage Rigidity in the UK, 1880-1985," Oxford Review of Economic Policy, 4, pp. 74-86.

Hatton, T. J. (1988b), “A Quarterly Model of the Labour Market in Interwar Britain,” Oxford Bulletin of Economics and Statistics, 50, pp. 1-26.

Hatton, T. J. (2003), “Unemployment and the Labour Market, 1870-1939," in R. C. Floud and P. A. Johnson (eds.), The Cambridge Economic History of Modern Britain, Cambridge: Cambridge University Press.

Hatton, T. J. (2007), "Can Productivity Growth Explain the NAIRU? Long Run Evidence from Britain, 1870-1999," Economica, 74, pp. 475-91

Hatton, T. J. and Bailey R. E (2002), "Unemployment Incidence in Interwar London," Economica, 69, pp. 631-54.

International Labour Review (1942), "The Impact of War on Long Term Unemployment in Great Britain," 45, pp. 45-

Jensen, R. (1989), "The Causes and Cures of Unemployment in the Great Depression," Journal of Interdisciplinary History, 19, pp. 553-83.

Keynes, J. M. (1931), Essays in Persuasion, London: Macmillan.

Kesselman, J. R. and Savin, N. E. (1978), "Three-and-a-half Million Workers Never Were Lost," Economic Inquiry, 16, pp. 205-25.

Layard, R., Nickell, S. J. and Jackman, R. (2005), Unemployment, Macroeconomic Performance and the Labour Market ( $2^{\text {nd }}$ Edn.), Oxford: Oxford University Press.

Llaudes, R. (2005), “The Phillips Curve and Long-term Unemployment,” Frankfurt: ECB Working Paper no. 441.

Long, C. D. (1944), The Labor Force in Wartime America, New York: National Bureau of Economic Research.

Margo, R. A. (1991), "The Microeconomics of Depression Unemployment," Journal of Economic History, 51, pp. 333-41.

Margo, R. A. (1993), "Employment and Unemployment in the 1930s," Journal of Economic Perspectives, 7, pp. 41-59.

Martin, B. (2011), "Is the British Economy Supply Constrained? A Critique of Productivity Pessimism," UK-IRC Report: University of Cambridge.

Matthews, K. G. P. (1986), The Interwar Economy: An Equilibrium Analysis, Aldershot: Gower. 
Montgomery, D. (1987), The Fall of the House of Labor: The Workplace, the State, and American Labor Activism, 1865-1925. New York: Cambridge University Press.

Moss, D. A. (2002), When All Else Fails: Government as the Ultimate Risk Manager, Cambridge MA: Harvard University Press.

Neumann, T. C., Fishback, P. V. and Kantor, S. (2010) "The Dynamics of Relief Spending and the Private Urban Labour Market during the New Deal," Journal of Economic History, 70, pp. 195-220.

Nickell, S. J. (1997), "Unemployment and Labor Market Rigidities: Europe versus North America," Journal of Economic Perspectives, 11, pp. 55-74.

Nickell, S. J. (1998), “Unemployment: Questions and Some Answers," Economic Journal, 108, pp. 802-16.

O'Brien, A. P. (1989), “A Behavioral Explanation for Nominal Wage Rigidity during the Great Depression," Quarterly Journal of Economics, 104, pp. 719-35.

Ohanian, L. E. (2009), “What - or Who - Started the Great Depression?” Journal of Economic Theory, 144, pp. 2310-2335.

Palmer, G. L. (1937), Recent Trends in Employment and Unemployment in Philadelphia, Philadelphia: University of Pennsylvania.

Pigou, A. C. (1927), "Wage Policy and Unemployment,” Economic Journal, 37, pp. 355-368.

Reinhart, C. M. and Reinhart, V. R. (2009), "When the North Last Headed South: Revisiting the 1930s," Brookings Papers in Economic Activity, Fall, pp. 251-272.

Reubens, B. C. (1945), “Unemployment in Wartime Britain,” Quarterly Journal of Economics, 59, pp. 206-236.

Romer, C. (1992), “What Ended the Great Depression?” Journal of Economic History, 52, pp. 757-784.

Rose, J. D. (2010), "Hoover's Truce: Wage Rigidity in the Onset of the Great Depression," Journal of Economic History, 70, pp. 843-870.

Rosenbloom, J. L. and Sundstrom, W. A. (1999), "The Sources of Regional Variation in the Severity of the Great Depression: Evidence from US Manufacturing, 1919-1937," Journal of Economic History, 59, pp. 714-747.

Rosenbloom, J. L. and Sundstrom, W. A. (2011), "Labor-Market Regimes in U.S. Economic History," in P. W.Rhode, J. L. Rosenbloom and D. F. Weiman (eds.), Economic Evolution and Revolutions in Historical Time, Stanford, CA: Stanford University Press.

Smiley, G. (1983), "Recent Unemployment Rate Estimates for the 1920s and 1930s," Journal of Economic History, 43, pp. 487-93. 
Soskice, D. (1990), "Wage Determination: The Changing Role of Institutions in Advanced Industrialized Countries," Oxford Review of Economic Policy, 6, pp. 36-61.

Temin, P. and Wigmore, B. A. (1990), “The End of One Big Deflation,” Explorations in Economic History, 27, pp. 483-502.

Thomas, M. (1983), "Rearmament and Economic Recovery in the Late 1930s," Economic History Review, 36, pp. 552-579.

Thomas, M. (1988), "Labour Market Structure and the Nature of Unemployment in Interwar Britain," in B. Eichengreen and T. J. Hatton (eds.), Interwar Unemployment in International Perspective, Dordrecht: Kluwer.

Thomas, M. (1992), "Institutional Rigidity in the British Labour Market, 1870-1939: A Comparative Perspective," in S. N. Broadberry and N. F. R. Crafts (eds.), Britain in the International Economy, 1870-1939, Cambridge: Cambridge University Press.

Thomas, M. (1994), "The Macro-economics of the Inter-war Years," in R. Floud and D. N. McCloskey, The Economic History of Britain since 1700, volume 2: 1860-1939, Cambridge: Cambridge University Press.

Thomas, R. L. and Stoney, P. J. M. (1971), Unemployment Dispersion as a Determinant of Wage Inflation in the U.K. 1925-66," Manchester School, 39, pp. 83-116.

Vatter, H. G. (1985), The U.S. Economy in World War II," New York: Columbia University Press.

Vedder, R. K. and Galloway, L. E. (1993), Out of Work: Unemployment and Government in Twentieth Century America, New York: Holmes and Meier.

Velde, F. R. (2009), “The Recession of 1937-A Cautionary Tale,” Economic Perspectives, 33 , pp. 16-37.

Vernon, J. R. (1991), “The 1920-21 Deflation: the Role of Aggregate Supply,” Economic Inquiry, 29, pp. 572-80.

Vernon, J. R. (1994), "World War II Fiscal Policies and the End of the Great Depression," Journal of Economic History, 54, pp. 850-868.

Wallis, J. J. (1989), "Employment in the Great Depression: New Data and New Hypotheses," Explorations in Economic History, 26, pp. 45-72.

Wallis, J. J. (2010), "Lessons from the Political Economy of the New Deal," Oxford Review of Economic Policy, 26, pp. 442-462.

Wallis, J. J. and Benjamin, D. K. (1981), "Public Relief and Private Employment in the Great Depression," Journal of Economic History, 41, pp. 97-102. 
Weinstein, M. (1980), Recovery and Redistribution under the NIRA, Amsterdam: North Holland.

Weir, D. R. (1992), “A Century of U.S. Unemployment, 1890-1990: Revised Estimates and Evidence for Stabilization," Research in Economic History, 14, pp. 301-46.

Whaples, R. (1990), “Winning the Eight-Hour Day, 1909-1919,” Journal of Economic History, 50, pp. 393-406.

Wolcott, S. (1993), "Keynes vs. Churchill: Sterling Overvaluation and British Unemployment in the Twenties," Journal of Economic History, 53, pp. 601-28. 


\section{Table 1}

\section{Unemployment in the UK and US 1891-1913 and 1920-1939}

(Dependent variable: $\log U_{t}$ )

\begin{tabular}{|l|l|l|l|l|l|l|}
\hline & UK & UK & US & US & $\begin{array}{l}\text { Difference } \\
\text { UK- US }\end{array}$ & $\begin{array}{l}\text { Difference } \\
\text { UK- US }\end{array}$ \\
\hline Constant & 0.59 & 0.84 & 0.77 & 0.72 & -0.00 & -0.01 \\
& $(3.73)$ & $(4.7)$ & $(4.3)$ & $(4.3)$ & $(0.1)$ & $(0.1)$ \\
\hline Log $\mathrm{U}_{\mathrm{t}-1}$ & 0.66 & 0.52 & 0.56 & 0.59 & 0.62 & 0.62 \\
& $(7.4)$ & $(5.2)$ & $(5.4)$ & $(6.1)$ & $(5.84)$ & $(6.0)$ \\
\hline$\Delta \Delta \log \mathrm{P}_{\mathrm{t}}$ & -3.77 & & -1.86 & & -0.78 & \\
& $(6.5)$ & & $(3.0)$ & & $(0.9)$ & \\
\hline$\Delta \Delta \log \mathrm{W}_{\mathrm{t}}$ & & -2.87 & & -2.08 & & -0.81 \\
& & $(4.1)$ & & $(4.0)$ & & $(1.4)$ \\
\hline Dummy & 0.17 & 0.24 & -0.14 & -0.14 & 0.37 & 0.37 \\
$1921-1939$ & $(2.2)$ & $(2.8)$ & $(1.2)$ & $(1.3)$ & $(3.1)$ & $(3.2)$ \\
\hline Dummy & 0.10 & 0.12 & 0.61 & 0.58 & -0.51 & -0.51 \\
$1930-1939$ & $(1.2)$ & $(1.1)$ & $(4.0)$ & $(4.0)$ & $(3.6)$ & $(3.7)$ \\
\hline Adj $\mathrm{R}^{2}$ & 0.83 & 0.75 & 0.74 & 0.77 & 0.61 & 0.62 \\
\hline DW & 1.62 & 1.93 & 1.52 & 1.32 & 1.85 & 1.86 \\
\hline No obs. & 43 & 43 & 43 & 43 & 43 & 43 \\
\hline
\end{tabular}

Table 2: Insured Unemployment Rates in UK Regions.

\begin{tabular}{|l|r|r|r|r|}
\hline Region & 1924 & 1929 & 1932 & 1936 \\
\hline London & 9.0 & 5.6 & 13.5 & 7.2 \\
\hline South East & 7.5 & 5.6 & 14.3 & 7.3 \\
\hline South West & 9.1 & 8.1 & 17.1 & 9.4 \\
\hline Midlands & 9.0 & 9.3 & 20.1 & 9.2 \\
\hline North East & 10.9 & 13.7 & 28.5 & 16.8 \\
\hline North West & 12.9 & 13.3 & 25.8 & 17.1 \\
\hline Scotland & 12.4 & 12.1 & 27.7 & 18.7 \\
\hline Wales & 8.6 & 19.3 & 36.5 & 29.4 \\
\hline N. Ireland & 16.6 & 14.8 & 27.2 & 22.7 \\
\hline Variance & 8.2 & 20.7 & 58.5 & 59.0 \\
\hline UK & 10.3 & 10.4 & 22.1 & 13.1 \\
\hline
\end{tabular}

Source: Booth and Glynn (1975) p. 619. 
Table 3: UK Unemployment Durations of Insured Men by Region

\begin{tabular}{|l|r|r|r|r|r|r|r|r|}
\hline & \multicolumn{4}{|c|}{ June 1932 } & \multicolumn{4}{c|}{ June 1936 } \\
\hline Region & $\begin{array}{c}\text { Unemp } \\
\text { Rate }\end{array}$ & Duration & $\begin{array}{c}\text { Spell } \\
\text { Length }\end{array}$ & $\begin{array}{c}\text { Share } \\
\text { LTU }\end{array}$ & $\begin{array}{c}\text { Unemp } \\
\text { Rate }\end{array}$ & Duration & $\begin{array}{c}\text { Spell } \\
\text { Length }\end{array}$ & $\begin{array}{c}\text { Share } \\
\text { LTU }\end{array}$ \\
\hline Gt. Britain & 28.3 & 10.5 & 26.5 & 17.3 & 13.8 & 12.1 & 42.2 & 26.6 \\
\hline London & 13.5 & 7.1 & 14.5 & 4.4 & 6.7 & 5.7 & 18.5 & 8.4 \\
\hline South East & 14.3 & 6.4 & 14.1 & 3.8 & 5.4 & 6.0 & 18.7 & 8.5 \\
\hline South West & 17.1 & 7.8 & 17.9 & 8.8 & 8.2 & 7.2 & 23.6 & 14.1 \\
\hline Midlands & 20.1 & 9.0 & 25.5 & 14.6 & 9.8 & 10.5 & 39.7 & 23.1 \\
\hline North East & 28.5 & 11.9 & 32.0 & 21.0 & 20.4 & 11.5 & 50.9 & 28.7 \\
\hline North West & 25.8 & 10.3 & 29.1 & 18.3 & 17.2 & 13.2 & 46.1 & 27.2 \\
\hline Scotland & 27.7 & 17.3 & 34.1 & 27.6 & 17.2 & 19.9 & 58.3 & 34.6 \\
\hline Wales & 36.5 & 11.0 & 29.6 & 21.1 & 33.0 & 18.6 & 64.6 & 37.7 \\
\hline
\end{tabular}

Source: Thomas (1988), p. 124.

Notes: Data refer to the insured unemployed only. Share LTU is the proportion unemployed for more than a year; Duration is the average completed duration, in weeks, for a worker flowing into unemployment; Spell length is the average interrupted spell length of those on the register, in weeks.

Table 4: US Unemployment Durations for Adult Males by Region, 1940

\begin{tabular}{|l|r|r|r|r|r|r|}
\hline & \multicolumn{3}{|c|}{ exc. relief workers } & \multicolumn{3}{c|}{ inc. relief workers } \\
\hline Region & $\begin{array}{c}\text { Unemp } \\
\text { Rate }\end{array}$ & $\begin{array}{c}\text { Spell } \\
\text { Length }\end{array}$ & $\begin{array}{c}\text { Share } \\
\text { LTU }\end{array}$ & $\begin{array}{c}\text { Unemp } \\
\text { Rate }\end{array}$ & $\begin{array}{c}\text { Spell } \\
\text { Length }\end{array}$ & Share LTU \\
\hline United States & 11.16 & 60.28 & 33.22 & 17.97 & 101.76 & 41.38 \\
\hline New England & 11.56 & 55.55 & 32.45 & 17.67 & 99.65 & 41.75 \\
\hline Mid Atlantic & 15.27 & 73.69 & 42.11 & 19.98 & 97.19 & 46.46 \\
\hline East North Central & 10.51 & 66.05 & 35.10 & 17.44 & 124.04 & 46.02 \\
\hline West North Central & 11.31 & 58.43 & 30.00 & 20.25 & 118.08 & 41.67 \\
\hline South Atlantic & 7.51 & 45.51 & 26.39 & 13.01 & 87.41 & 35.90 \\
\hline East South Central & 9.54 & 49.35 & 28.83 & 17.68 & 102.02 & 38.06 \\
\hline West South Central & 11.07 & 43.04 & 22.82 & 18.72 & 91.58 & 34.18 \\
\hline Mountain & 13.14 & 44.21 & 23.40 & 23.06 & 95.84 & 33.00 \\
\hline Pacific & 12.30 & 44.85 & 21.77 & 17.26 & 76.16 & 31.27 \\
\hline
\end{tabular}

Source: Calculated from IPUMS 1 per cent sample of 1940 Census returns; excluding employers and self-employed.

Notes: Data refer to 16-65 year old males only. Relief workers are counted as employed in the first three columns and as unemployed in the final three columns. Variables defined as in Table 3. 


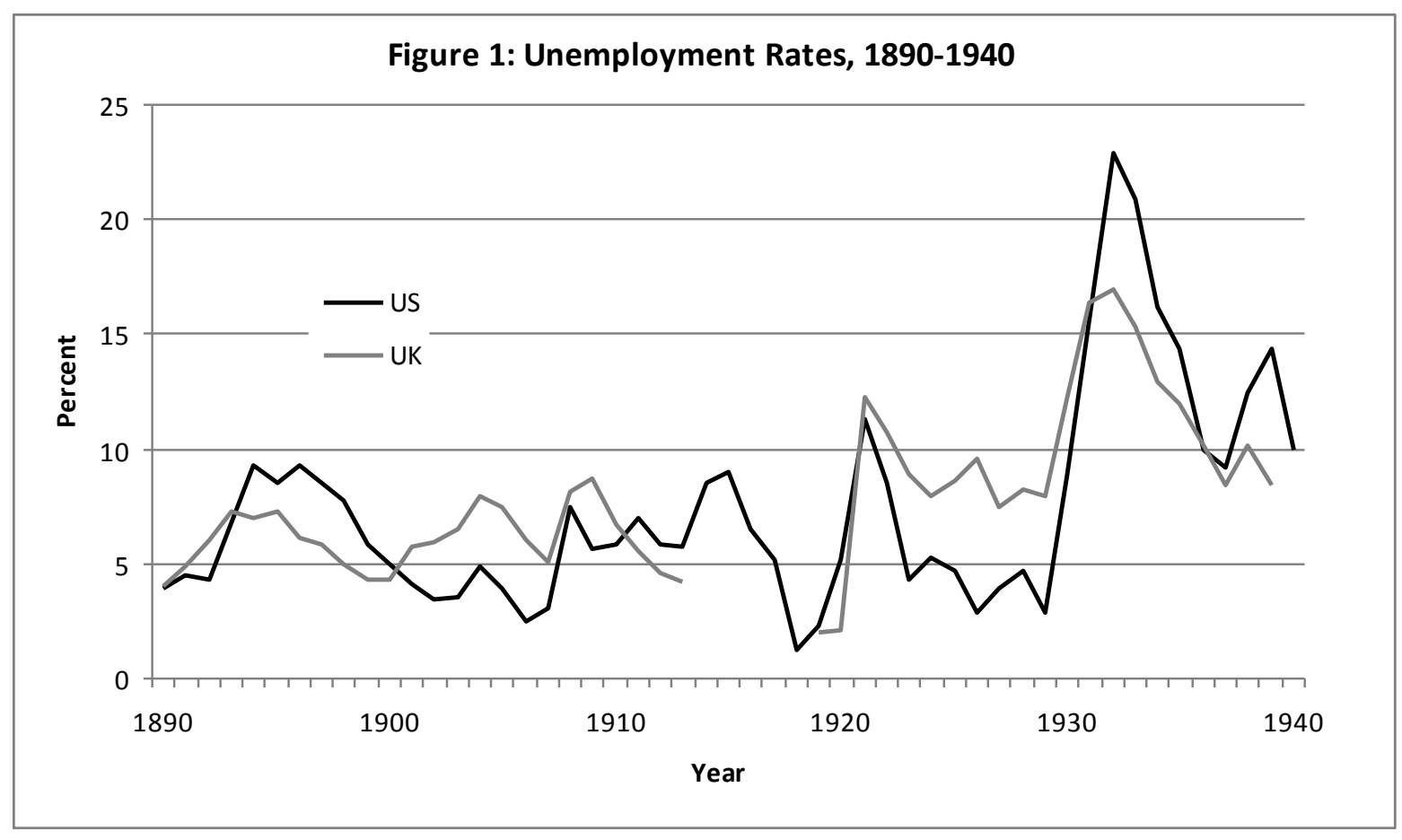

Sources: US: Weir (1992), p. 341-2; UK: Boyer and Hatton (2002), p. 667.

Notes: For the US in the 1930s relief workers are counted as employed.

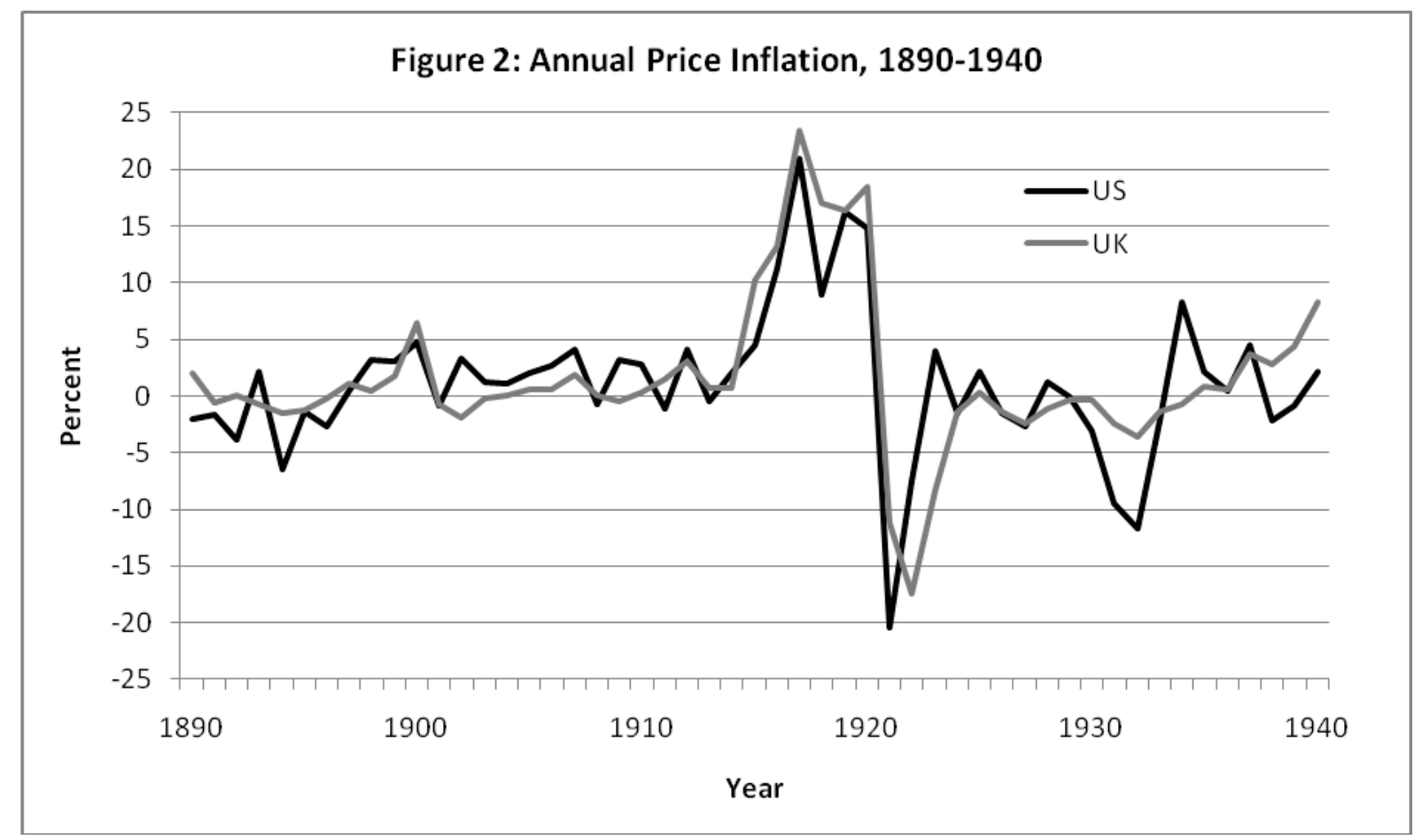

Sources: US: Balke and Gordon (1986) pp. 782-3; UK: Feinstein (1972) pp. T132-3. 


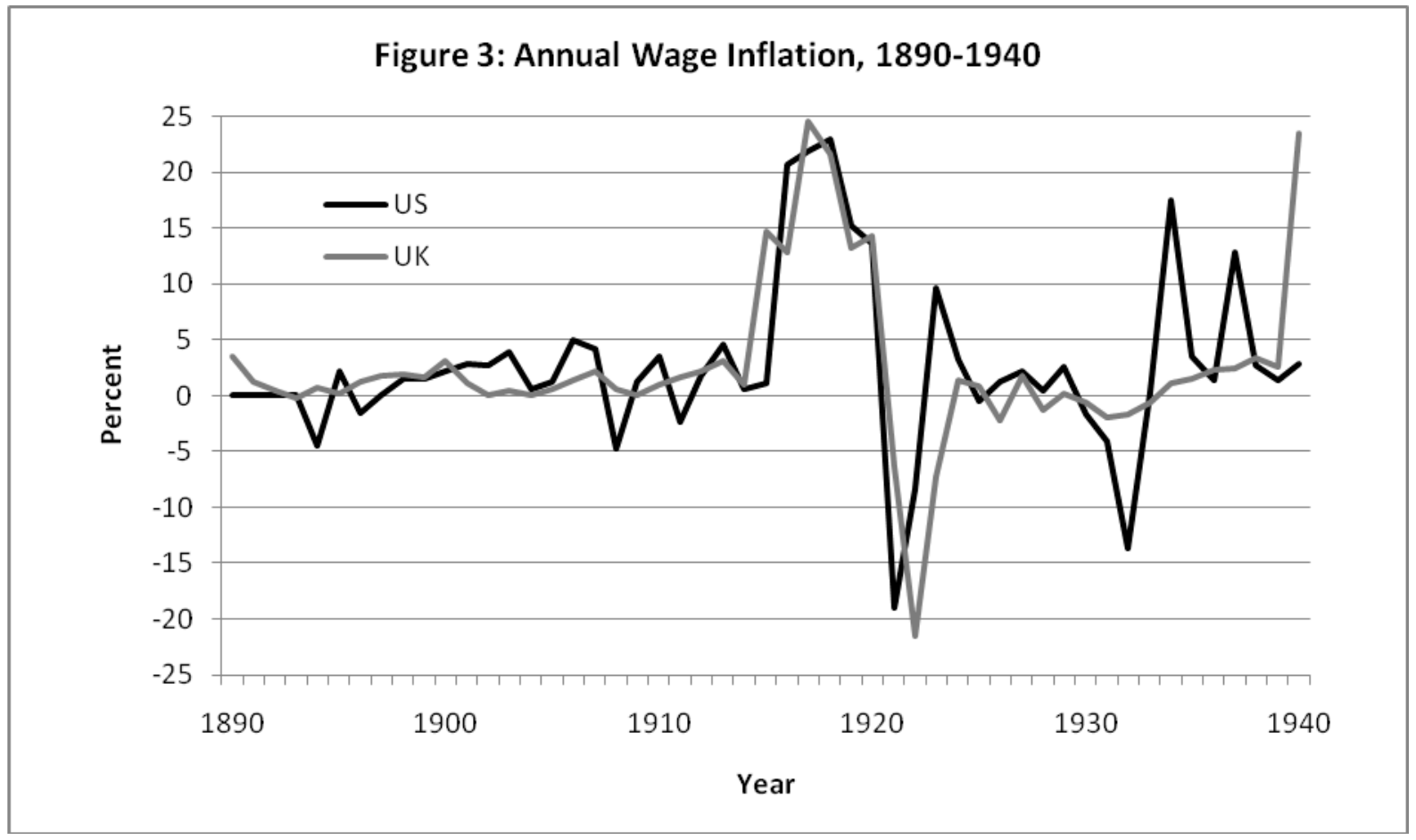

Source: US: David and Solar, (1977), p. 59; UK: Feinstein (1995), pp. 263-266.

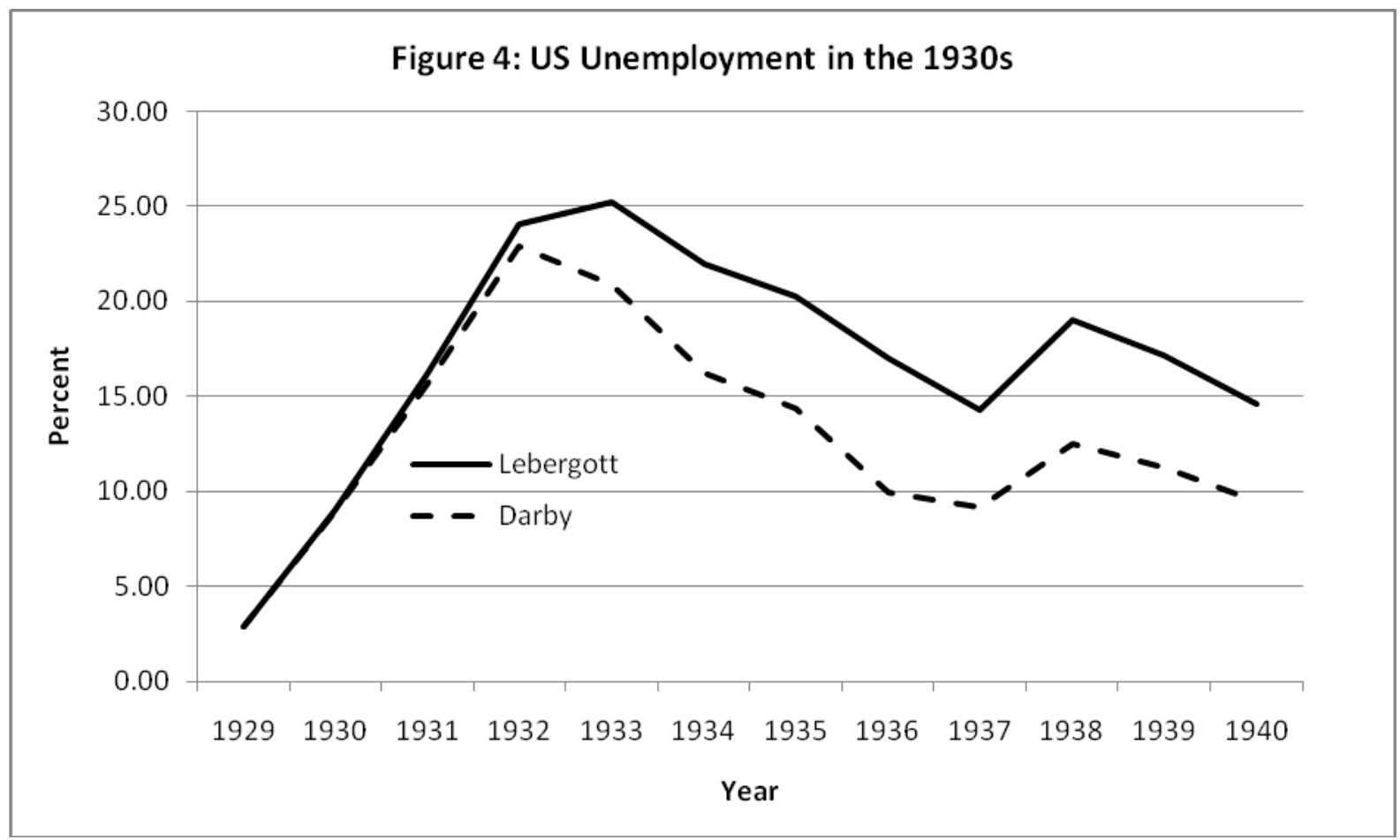

Source: Smiley (1983) p. 488. 